\title{
Kesantunan Berbahasa Siswa Kelas 5 SD Di Kecamatan Tamalanrea Kota Makassar
}

\section{Characteristics Of Language Students For Grade 5 SD In The Tamalanrea Sub-District Makassar City}

\author{
Nur Santy Abidin ${ }^{1}$, Mas'ud Muhammadiah $^{2}$, A. Hamsiah ${ }^{2}$ \\ ${ }^{1}$ Dinas Pendidikan Kota Makassar, Sulawesi Selatan \\ ${ }^{2}$ Program Studi Studi Pendidikan Dasar, Program Pascasarjana, Universitas Bosowa \\ E-mail: nursanty_ismail@yahoo.com
}

Diterima: 10 Januari 2021/Disetujui 09 Juni 2021

\begin{abstract}
Abstrak. Penelitian ini bertujuan untuk mendeskripsikan realisasi kesantunan dan penyimpangan berbahasa siswa kelas 5 SD di kecamatan Tamalanrea kota Makassar. Penelitian ini dilakukan di SD Kecamatan Tamalanrea Makassar. Subjek penelitian ini adalah siswa kelas 5 SD Inpres Tamalanrea 1, SD Inpres Tamalanrea 3, dan SD Inpres Tamalanrea 4. Teknik pengumpulan data dalam penelitian ini menggunakan observasi dan rekaman. Peneliti mengolah data secara kualitatif. Penelitian ini menghasilkan bentuk percakapan kesantunan dan penyimpangan berbahasa.
\end{abstract}

Kata Kunci: Kesantungan Berbahasa, Penyimpangan Kesantunan

\begin{abstract}
This study aims to describe the realization of politeness and language deviations in 5th grade elementary school students in the Tamalanrea district, Makassar city. This research was conducted in elementary schools (SD) in Tamalanrea District, Makassar. The subjects of this study were 5th grade students of SD Inpres Tamalanrea 1, SD Inpres Tamalanrea 3, and SD Inpres Tamalanrea 4. Data collection techniques in this study using observation and recording. The researcher processed the data qualitatively. This research produces conversational forms of politeness and language deviations.
\end{abstract}

Keywords: Language Politeness, Deviation of Politeness

\section{Pendahuluan}

Bahasa memegang peranan penting dalam kehidupan manusia. Manusia menggunakan bahasa sebagai sarana untuk berkomunikasi. Bahasa merupakan sistem lambang dapat dimanfaatkan masyarakat tertentu dalam bekerja sama dan berinteraksi (Kridalaksana, 1993). Pada kegiatan interaksi, perlu aturan yang mengatur para peserta tuturan supaya terjalin komunikasi yang baik dari keduanya. Pemakaian bahasa sebagai alat komunikasi dipengaruhi oleh faktor sosial dan faktor situasional. Faktor-faktor sosial yang mempengaruhi pemakaian bahasa adalah status sosial, jenis kelamin, umur, tingkat pendidikan, tingkat ekonomi dan sebagainya. Faktor situasional meliputi siapa yang berbicara dengan bahasa apa, kepada siapa, kapan, di mana, mengenai hal apa, dalam situasi yang bagaimana, apa jalur yang digunakan, ragam bahasa mana yang digunakan, serta tujuan pembicara (Nababan, 1986).

Berbahasa berkaitan dengan pemilihan jenis kata, lawan bicara, waktu (situasi) dan tempat (kondisi) diperkuat dengan cara pengungkapan yang menggambarkan nilai-nilai budaya masyarakat. Dewasa ini, masyarakat sedang mengalami perubahan menuju era globalisasi (Asdar, 2019). Setiap perubahan masyarakat melahirkan konsekuensi-konsekuensi tertentu yang berkaitan dengan nilai dan moral, termasuk pergeseran bahasa dari bahasa santun menuju kepada bahasa yang tidak santun. Tindak tutur atau dalam istilah Inggris speech act merupakan aktivitas mengujarkan atau menuturkan tuturan dengan maksud tertentu (Rustono, 1999). Orang yang ketika berbicara menggunakan pilihan kata, ungkapan yang santun, struktur kalimat yang baik menandakan bahwa kepribadian orang itu memang baik (Jainuddin, 2019). Sebaliknya, jika ada orang yang sebenarnya kepribadiannya tidak baik, meskipun berusaha berbahasa secara baik, benar, dan santun di hadapan orang lain, pada suatu saat tidak mampu menutup-nutupi kepribadian buruknya sehingga muncul pilihan kata, ungkapan, atau struktur kalimat yang tidak baik dan tidak santun. Kehidupan berbahasa dalam bermasyarakat merupakan sutu kunci untuk memperbaiki atau meluruskan tata cara berkomunikasi (Darmawan, 20210.

Dewasa ini, tidak sedikit orang menggunakan bahasa secara bebas tanpa didasari oleh pertimbangan-pertimbangan moral, nilai, maupun agama. Akibat kebebasan tanpa nilai itu, lahir berbagai pertentangan dan perselisihan di kalangan masyarakat. Kini tidak sedikit kaum remaja Indonesia yang tampak seolah tidak mengenal etika kesantunan yang semestinya ia tunjukan sebagai hasil dari pendidikan di keluarga, sekolah dan masyarakat (Jainuddin dkk, 2020). Kondisi demikian menjadikan terkikisnya karakter bangsa Indonesia yang sejatinya dikenal dengan bangsa berkarakter santun.

Kesantunan berbahasa menjadi bagian yang penting dalam membentuk karakter atau sikap seseorang dan membentuk sikap dengan orang lain. Bahasa yang digunakan dapat diketahui kepribadian seseorang. Tuturan seseorang disebut santun relatif pada ukuran atau kadar kesantunan dalam masyarakat pengguna bahasa tersebut. Dalam Bahasa Indonesia, tuturan santun apabila tidak mengandung ejekan secara langsung, tidak memerintah secara langsung, tidak dengan sengaja menyakiti hati orang lain, dan menghormati atau menghargai orang lain. Pemikiran utama maksim kebijaksanaan/tact maximdalam 
prinsipkesantunan yaitu peserta petuturan sebaiknya berpegang terhadap prinsip agar meminimalkan keuntungan bagi diri sendiri sertamemperbanyak keuntungan pihak lain saat berkomunikasi. Apabila dalam bertutur orang berpegang teguh pada maksim kebijaksanaan, ia akan dapat menghindarkan sikap dengki, iri hati, dan sikap-sikap lain yang kurang santun terhadap mitra tutur (Rahardi, 2005).

Pelanggaran prinsip kesantunan sering terjadi dalam komunikasi antar individu, baik dalam ranah formal maupun nonformal. Salah satu bentuk komunikasi formal terdapat di sekolah. Sekolah memiliki peran penting dalam menciptakan dan membentuk kesantunan berbahasa siswa. Siswa yang berbahasa tidak santun akan berakibat pada generasi berikutnya, yakni generasi yang kasar, minim nilai etika, dan tidak berkarakter.

Dari segi pendidik, guru perlu memberi bimbingan dan memahami situasi untuk tujuan terjalinnya kerja sama komunikasi yang baik, harmonis, dan sesuai alur dalam etika kesantunan berbahasa. Hal tersebut merujuk pada penggunaan tuturan yang baik dan sesuai konteks dalam kelas agar tercipta suasana belajar mengajar yang berkesan bagi guru dan siswa. Guru berperan penting dalam berbagai hal, seperti mempersiapkan konteks dan materi, berkreativitas dalam memanfaatkan lingkungan, berkreativitas mengatur situasi dalam pembelajaran, dan membimbing siswa dalam memahami dan memecahkan masalah selama pembelajaran berlangsung (Gojkov, 2010).

Berdasarkan observasi semula, peneliti melihat bahwa siswa masih sering menggunakan kata-kata yang kurang santun ketika melakukan percakapan tidak saja di luar kelas bahkan ketika berada di dalam kelas siswa juga menggunakan kata-kata yang kurang santun. Tentu saja hal ini bukan merupakan contoh yang baik karena ketika berada di lingkungan sekolah baik di dalam kelas maupun di luar kelas seharusnya siswa menggunakan bahasa yang santun dalam percakapannya.

Kesantunan berbahasa terkait langsung dengan norma yang dianut oleh masyarakatnya. Jika masyarakat menerapkan norma dan nilai secara ketat, maka berbahasa santun pun menjadi bagian dari kebiasaan masyarakat. Dalam kaitan dengan pendidikan, maka masyarakat yang menjunjung tinggi nilai kesantunan akanmenjadikan berbahasa santun sebagai bagian penting dari proses pendidikan, khususnya pendidikan persekolahan. Penelitian ini bertujuan untuk mendeskripsikan realisasi kesantunan dan penyimpangan berbahasa siswa kelas 5 SD di kecamatan Tamalanrea kota Makassar. Penelitian ini dilakukan di SD Kecamatan Tamalanrea Makassar. Subjek penelitian ini adalah siswa kelas 5 SD Inpres Tamalanrea 1, SD Inpres Tamalanrea 3, dan SD Inpres Tamalanrea 4. Dari banyaknya penelitian yang dilakukan mengenai kesantunan penulis beranggapan bahwa penelitian mengenai kesantunan berbahasa siswa kelas 5 SD di kecamatan Tamalanrea kota Makassar sangat menarik dan perlu untuk dilakukan.

\section{Metode Penelitian}

Jenis penelitian yang dipakai oleh penulis yaitu metode deskriptif dengan pendekatan kualitatif. Metodologi kualitatif ialah prosedur penelitian dengan hasil berupa data deskriptif (kata tertulis atau lisan dan perilaku) yang dapat diamati melalui subjek itu sendiri (Taylor \& Bogdan, 1998).

Penelitian ini dilakukan pada bulan Agustus, 2020 di Kecamatan Tamalanrea. Peneliti mengambil sampel penelitian sebanyak 3 sekolah yaitu SD Inpres Tamalanrea 1, SD Inpres Tamalanrea 3, dan SD Inpres Tamalanrea 4. Peneliti memilih 3 sekolah ini karena memiliki situasi, kondisi dan karakteristik siswa yang hampir sama.

Tahapan yang peneliti lakukan pada teknik pengumpulan data seperti observasi atau pengamatan, pengumpulan data dalam bentuk rekaman, reduksi data dilakukan dengan cara memilih data penting lalu menyingkirkan yang tidak penting. penyajian data, yaitu mengklasifikasikan data sejenis serta penarikan simpulan.

Teknik analisis data dilakukan melalui beberapa tahapan yaitu:

1. Persiapan

Kegiatan yang dilakukan dalam langkah persiapan ini adalah sebagai berikut.

a. Mengecek alat-alat yang diperlukan.

b. Merekam lalu mencatat yang dianggap perlu.

2. Pelaksanaan

Tahap pelaksanaan dalam penelitian ini, yaitu mereduksi data dilakukan melalui proses penyeleksian, identifikasi, dan pengklasifikasian. Penyeleksian dan pengidentifikasian merupakan kegiatan untuk menyeleksi dan mengidentifikasikan data-data sesuai dengan prinsip sopan santun Leech, sedangkan tahap pengklasifikasian merupakan proses yang dilakukan untuk mengklasifikasikan data, memilih data, dan mengelompokan data ke dalam prinsip sopan santun.

3. Analisis

Dalam tahap ini, yang dilakukan peneliti adalah menganalis data-data yang diperoleh dari hasil rekaman dan catatan lapangan, yang merupakan tindak lanjut dari reduksi data lalu menganalisisnya. Teknik yang digunakan untuk menganalisis data adalah (1) mentranskripsikan bahasa lisan siswa yang telah direkam berupa data lisan ke dalam bahasa tulis, (2) menginventariskan kesantunan bahasa lisan siswa pada saat kegiatan di luar kelas (3) mengklasifikasikan bahasa lisan siswa ke dalam teori prinsip sopan santun.

4. Menyimpulkan

Setelah data penelitian dianalisis, kemudian diambil sebuah simpulan untuk menjelaskan kesantunan bahasa lisan siswa. 


\section{Hasil dan Pembahasan}

\section{a. Pematuhan Kesantunan Berbahasa}

Pematuhan prinsip kesantunan berbahasa yang ditemukan dalam percakapan di luar kelas pada siswa kelas 5 SD di kecamatan Tamalanrea yang terdiri dari 32 rekaman percakapan. Data pematuhan prinsip kesantunan tersebut berupa maksim kearifan, kedermawanan, pujian, kerendahan hati, kesepakatan, dan kesimpatian. Pematuhan prinsip kesantunan ini berupa pematuhan satu maksim, dua maksim, dan tiga maksim sekaligus dalam satu rekaman percakapan. Berikut ini ditampilkan tabel hasil penelitian pematuhan prinsip kesantunan.

Tabel 1. Pematuhan Prinsip Kesantunan Berbahasa pada siswa SD Inpres Tamalanrea 1

\begin{tabular}{|c|c|c|c|c|c|c|c|}
\hline \multirow{2}{*}{ Rekaman ke } & \multicolumn{6}{|c|}{ Maksim } & \multirow{2}{*}{ Keterangan } \\
\hline & Kearifan & Kedermawanan & Pujian & Kerendahan hati & Kesepakatan & Simpati & \\
\hline 1 & & & & $\sqrt{ }$ & $\sqrt{ }$ & & 2 maksim \\
\hline 2 & $\sqrt{ }$ & & $\sqrt{ }$ & $\sqrt{ }$ & & & 3 maksim \\
\hline 3 & & & & & $\sqrt{ }$ & & 1 maksim \\
\hline 4 & & & $\sqrt{ }$ & $\sqrt{ }$ & & & 2 maksim \\
\hline 5 & & & & & $\sqrt{ }$ & & 1 maksim \\
\hline 6 & & & & $\sqrt{ }$ & $\sqrt{ }$ & & 2 maksim \\
\hline 7 & & $\sqrt{ }$ & & & $\sqrt{ }$ & $\sqrt{ }$ & 3 maksim \\
\hline 8 & & & & & $\sqrt{ }$ & & 1 maksim \\
\hline 9 & & & & & $\sqrt{ }$ & & 1 maksim \\
\hline 10 & & & & & $\sqrt{ }$ & $\sqrt{ }$ & 2 maksim \\
\hline 11 & $\sqrt{ }$ & & & & $\sqrt{ }$ & & 2 maksim \\
\hline 12 & & & $\sqrt{ }$ & & & & 1 maksim \\
\hline 13 & & & & $\sqrt{ }$ & $\sqrt{ }$ & & 2 maksim \\
\hline
\end{tabular}

Sumber: Analisa Data, 2020

Tabel 2 Pematuhan Prinsip Kesantunan Berbahasa pada siswa SD Inpres Tamalanrea 3

\begin{tabular}{|c|c|c|c|c|c|c|c|}
\hline \multirow{2}{*}{ Rekaman ke } & \multicolumn{6}{|c|}{ Maksim } & \multirow{2}{*}{ Keterangan } \\
\hline & Kearifan & Kedermawanan & Pujian & Kerendahan hati & Kesepakatan & Simpati & \\
\hline 1 & $\sqrt{ }$ & & & & $\sqrt{ }$ & & 2 maksim \\
\hline 2 & & & & & & $\sqrt{ }$ & 1 maksim \\
\hline 3 & & & & & $\sqrt{ }$ & & 1 maksim \\
\hline 4 & $\sqrt{ }$ & & $\sqrt{ }$ & & & & 2 maksim \\
\hline 5 & $\sqrt{ }$ & & & & & & 1 maksim \\
\hline 6 & & & & $\sqrt{ }$ & & & 1 maksim \\
\hline 7 & $\sqrt{ }$ & $\sqrt{ }$ & $\sqrt{ }$ & & & & 3 maksim \\
\hline 8 & $\sqrt{ }$ & & & & $\sqrt{ }$ & & 2 maksim \\
\hline 9 & & & $\sqrt{ }$ & & & & 1 maksim \\
\hline 10 & $\sqrt{ }$ & & & & & & 1 maksim \\
\hline 11 & & $\sqrt{ }$ & & & $\sqrt{ }$ & & 2 maksim \\
\hline
\end{tabular}

Sumber: Analisa Data, 2020

Tabel 3. Pematuhan Prinsip Kesantunan Berbahasa pada siswa SD Inpres Tamalanrea 4

\begin{tabular}{|c|c|c|c|c|c|c|c|}
\hline \multirow{2}{*}{ Rekaman ke } & \multicolumn{6}{|c|}{ Maksim } & \multirow[b]{2}{*}{ Keterangan } \\
\hline & Kearifan & Kedermawanan & Pujian & Kerendahan hati & Kesepakatan & Simpati & \\
\hline 1 & $\sqrt{ }$ & & & $\sqrt{ }$ & & & 2 maksim \\
\hline 2 & & & & & $\sqrt{ }$ & & 1 maksim \\
\hline 3 & $\sqrt{ }$ & & & & $\sqrt{ }$ & & 2 maksim \\
\hline 4 & $\sqrt{ }$ & $\sqrt{ }$ & & $\sqrt{ }$ & & & 3 maksim \\
\hline 5 & $\sqrt{ }$ & & & & $\sqrt{ }$ & & 2 maksim \\
\hline 6 & & $\sqrt{ }$ & & & $\sqrt{ }$ & $\sqrt{ }$ & 3 maksim \\
\hline 7 & $\sqrt{ }$ & & $\sqrt{ }$ & & & & 2 maksim \\
\hline 8 & & & $\sqrt{ }$ & & & & 1 maksim \\
\hline
\end{tabular}

Sumber: Analisa Data, 2020

Dalam maksim kearifan ini, penutur hendaknya selalu mengurangi keuntungan dirinya sendiri dan memaksimalkan keuntungan pada pihak lain dalam bertutur. Pada saat akan berbicara dengan orang lain, penutur harus bersikap santun, bijaksana, tidak memberatkan lawan tutur, dan menggunakan kata yang halus dalam bertutur. Pematuhan maksim kearifan ini ditandai dengan pemilihan kata yang halus dalam bertanya, ataupun berpendapat. Misalnya menggunakan kata maaf, terima kasih, silahkan, mohon, dan tolong. Penutur juga tidak diperbolehkan menyindir dan memaksakan pendapatnya pada orang lain.

Maksim kedermawanan ini menuntut peserta pertuturan untuk membuat keuntungan pada diri sendiri sekecil mungkin, dan membuat kerugian pada diri sendiri sebanyak mungkin. Tuturan akan menjadi santun, jika penutur mampu menghormati orang lain dengan cara memaksimalkan keuntungan pada lawan tuturnya. 
Dalam maksim kesepakatan peserta tutur ditekankan dapat saling membina kecocokan atau kemufakatan di dalam kegiatan bertutur. Tuturan dikatakan santun jika antara penutur dan lawan tutur bisa memaksimalkan kecocokan di antara mereka.

Maksim pujian menuntut setiap penutur untuk memaksimalkan rasa hormat kepada orang lain, dan meminimalkan rasa tidak hormat pada diri sendiri. Tuturan dikatakan santun jika dapat memberi pujian untuk orang lain sehingga orang lain akan merasa senang. Pematuhan maksim pujian ditandai dengan sikap penutur yang mau menghargai pendapat orang lain, bisa memberikan kritik yang membangun, mampu memberikan pujian yang jujur pada pendapat orang lain, mau mengucapkan terima kasih ketika mendapat kritikan dari orang lain, tidak mempermalukan lawan tutur di muka umum, dan tidak menggunakan tuturan langsung saat mengkritik orang lain.

Dalam maksim kesimpatian ini diharapkan peserta tutur dapat memaksimalkan sikap simpati kepada orang lain. Tuturan akan terasa santun jika seseorang dapat menunjukkan sikap simpatinya dan tidak bersikap sinis terhadap orang lain. Pematuhan pada maksim ini ditandai dengan sikap penutur yang mau memberikan dukungan yang tulus pada orang lain yang pendapatnya benar, dan memberikan sikap simpati pada orang lain yang salah.

Maksim kerendahan hati, penutur diharapkan dapat bersikap rendah hati dengan cara mengurangi pujian terhadap dirinya sendiri.

\section{b. Penyimpangan / Pelanggaran Kesantunan Berbahasa}

Berdasarkan hasil penelitian, jumlah penyimpangan prinsip kesantunan berbahasa pada di luar kelas pada siswa kelas 5 SD di kecamatan Tamalanrea yang terdiri dari 32 rekaman percakapan. Data penyimpangan prinsip kesantunan berbahasa terdiri dari enam maksim, meliputi maksim kebijaksanaan, kesimpatian, penghargaan, kedermawanan, kesederhanaan dan permufakatan. Penyimpangan prinsip kesantunan berupa penyimpangan satu maksim, dua maksim dan tiga maksim sekaligus dalam satu tuturan. Hasil penelitian tersebut disajikan dalam tabel berikut.

Tabel 4 Jenis Penyimpangan / Pelanggaran Berbahasa pada siswa SD Inpres Tamalanrea 1

\begin{tabular}{|c|c|c|c|c|c|c|c|}
\hline \multirow{2}{*}{ Rekaman ke } & \multicolumn{6}{|c|}{ Jenis maksim } & \multirow{2}{*}{ Keterangan } \\
\hline & Kearifan & Kedermawanan & Pujian & Kerendahan hati & Kesepakatan & Simpati & \\
\hline 1 & & & & & & & - \\
\hline 2 & & & $\sqrt{ }$ & & & & 1 maksim \\
\hline 3 & & & & $\sqrt{ }$ & & $\sqrt{ }$ & 2 maksim \\
\hline 4 & & & & & & & - \\
\hline 5 & & & & & & & - \\
\hline 6 & & & & & & & - \\
\hline 7 & & $\sqrt{ }$ & & & $\sqrt{ }$ & & 2 maksim \\
\hline 8 & $\sqrt{ }$ & & & & & & \\
\hline 9 & & & & $\sqrt{ }$ & & $\sqrt{ }$ & 2 maksim \\
\hline 10 & & & & $\sqrt{ }$ & $\sqrt{ }$ & & 2 maksim \\
\hline 11 & & & $\sqrt{ }$ & & & $\sqrt{ }$ & 2 maksim \\
\hline 12 & & & $\sqrt{ }$ & $\sqrt{ }$ & & & 2 maksim \\
\hline 13 & & & & & & & - \\
\hline
\end{tabular}

Tabel 5 Jenis Penyimpangan / Pelanggaran Berbahasa pada siswa SD Inpres Tamalanrea 3

\begin{tabular}{|c|c|c|c|c|c|c|c|}
\hline \multirow{2}{*}{ Rekaman ke } & \multicolumn{6}{|c|}{ Jenis maksim } & \multirow{2}{*}{ Keterangan } \\
\hline & Kearifan & Kedermawanan & Pujian & Kerendahan hati & Kesepakatan & Simpati & \\
\hline 1 & $\sqrt{ }$ & & & & $\sqrt{ }$ & & 2 maksim \\
\hline 2 & $\sqrt{ }$ & & $\sqrt{ }$ & $\sqrt{ }$ & & & 3 maksim \\
\hline 3 & $\sqrt{ }$ & & & & & & 1 maksim \\
\hline 4 & & & $\sqrt{ }$ & & & & 1 maksim \\
\hline 5 & $\sqrt{ }$ & & $\sqrt{ }$ & & & & 2 maksim \\
\hline 6 & & & & $\sqrt{ }$ & & & 1 maksim \\
\hline 7 & $\sqrt{ }$ & & & $\sqrt{ }$ & $\sqrt{ }$ & & 3 maksim \\
\hline 8 & $\sqrt{ }$ & & & $\sqrt{ }$ & $\sqrt{ }$ & & 3 maksim \\
\hline 9 & & & $\sqrt{ }$ & & $\sqrt{ }$ & & 2 maksim \\
\hline 10 & & & & $\sqrt{ }$ & & & 1 maksim \\
\hline 11 & & & & & & & - \\
\hline
\end{tabular}

Sumber: Analisa Data, 2020

Tabel 6. Jenis Penyimpangan / Pelanggaran Berbahasa pada siswa SD Inpres Tamalanrea 4

\begin{tabular}{|c|c|c|c|c|c|c|c|}
\hline \multirow{2}{*}{ Rekaman ke } & \multicolumn{6}{|c|}{ Jenis maksim } & \multirow[t]{2}{*}{ Keterangan } \\
\hline & Kearifan & Kedermawanan & Pujian & Kerendahan hati & Kesepakatan & Simpati & \\
\hline 1 & & & $\sqrt{ }$ & $\sqrt{ }$ & & $\sqrt{ }$ & 3 maksim \\
\hline 2 & & & $\sqrt{ }$ & & $\sqrt{ }$ & & 2 maksim \\
\hline 3 & $\sqrt{ }$ & & $\sqrt{ }$ & & & & 2 maksim \\
\hline 4 & & & & & & & - \\
\hline 5 & & & & & & & - \\
\hline 6 & $\sqrt{ }$ & $\sqrt{ }$ & & & $\sqrt{ }$ & & 3 maksim \\
\hline 7 & & & & & & & - \\
\hline 8 & & & $\sqrt{ }$ & $\sqrt{ }$ & $\sqrt{ }$ & & 3 maksim \\
\hline
\end{tabular}


Dalam maksim ini, penutur hendaknya selalu mengurangi keuntungan dirinya sendiri dan memaksimalkan keuntungan pada pihak lain dalam bertutur. Pada saat akan berbicara dengan orang lain, penutur harus bersikap santun, bijaksana, tidak memberatkan lawan tutur, dan menggunakan diksi yang halus dalam bertutur. Penyimpangan maksim kearifan ini ditandai dengan pemilihan kosakata yang kasar dalam bertanya, berpendapat, sehingga dapat meminimalkan keuntungan pada orang lain.

Maksim pujian menuntut setiap penutur untuk memaksimalkan rasa hormat kepada orang lain, dan meminimalkan rasa tidak hormat pada diri sendiri. Tuturan dikatakan santun jika dapat memberi penghargaan untuk orang lain sehingga orang lain akan merasa senang. Penyimpangan dalam maksim ini ditandai dengan adanya sikap tidak mau menghargai pendapat orang lain, memberikan kritik yang menjatuhkan orang lain, dan berbicara yang merendahkan orang lain.

Maksim kedermawanan ini menuntut penutur untuk membuat keuntungan pada diri sendiri sekecil mungkin, dan membuat kerugian pada diri sendiri sebanyak mungkin. Tuturan akan menjadi santun, jika penutur mampu menghormati orang lain dengan cara memaksimalkan keuntungan pada lawan tuturnya.

Pada maksim ini penutur diharapkan dapat bersikap rendah hati, mengurangi pujian terhadap diri sendiri dan memaksimalkan kehormatan pada orang lain. Penyimpangan dalam maksim ini ditandai dengan sikap penutur yang berprasangka buruk terhadap lawan tutur dan penutur yang menonjolkan kelebihannya di depan orang lain.

Dalam maksim kesepakatan penutur ditekankan dapat saling membina kecocokan atau kemufakatan di dalam kegiatan bertutur. Tuturan dikatakan santun jika antara penutur dan lawan tutur bisa memaksimalkan kecocokan di antara mereka. Penyimpangan maksim permufakatan ditandai dengan sikap penutur yang tidak mau mendukung pendapat yang benar meskipun pendapatnya salah, penutur tidak mampu berbicara sesuai pokok permasalahan, dan penutur tidak mau menerima atau menyetujui pendapat orang lain.

Dalam maksim kesimpatian ini diharapkan penutur dapat memaksimalkan sikap simpati kepada orang lain. Tuturan akan terasa santun jika seseorang dapat menunjukkan sikap simpatinya dan tidak bersikap sinis terhadap orang lain. Penyimpangan pada maksim ini ditandai dengan sikap penutur yang tidak mau memberikan dukungan yang tulus pada orang lain yang pendapatnya benar, dan tidak memberikan sikap simpati pada orang lain yang salah.

\section{Kesimpulan dan Saran}

Hasil penelitian dapat disimpulkan bahwa pematuhan prinsip kesantunan siswa kelas 5 SD Di Kecamatan Tamalanrea berupa pematuhan satu maksim yaitu maksim kearifan, maksim kedermawanan, maksim kesepakatan, maksim kesimpatian, dan maksim pujian. Terdapat pula pematuhan dua maksim seperti maksim kearifan dan maksim kesepakatan, maksim kearifan dan maksim kedermawanan, maksim kearifan dan maksim pujian, maksim pujian dan maksim kesepakatan, maksim kesepakatan dan kesimpatian, serta maksim pujian dan kesimpatian. Sementara itu, terdapat pula pematuhan tiga maksim yakni maksim kearifan, maksim kesepakatan, dan maksim kesimpatian. Dari maksim-maksim di atas, maksim yang paling banyak dipatuhi adalah maksim kearifan. Pada maksim kearifan tersebut, indikator yang paling banyak dipatuhi adalah pemilihan kata yang halus dalam bertanya, berpendapat, dan menyanggah pendapat orang lain. Penyimpangan prinsip kesantunan siswa kelas 5 SD Di Kecamatan Tamalanrea berupa penyimpangan satu maksim seperti penyimpangan maksim kearifan, maksim pujian, maksim kedermawanan, maksim kerendahan hati, maksim kesepakatan dan maksim kesimpatian. Terdapat pula penyimpangan dua maksim yakni penyimpangan maksim pujian dan maksim kesimpatian, maksim pujian dan maksim kerendahan hati, maksim kearifan dan maksim kedermawanan, maksim kearifan dan maksim pujian, serta maksim kearifan dan maksim kesimpatian. Selain itu, terdapat penyimpangan tiga maksim yakni maksim kearifan, maksim kedermawanan dan maksim pujian. Di antara maksim-maksim tersebut, maksim yang paling banyak disimpangkan adalah maksim pujian, kearifan dan kedermawanan.

\section{Daftar Pustaka}

Asdar, A., Hamsiah, H., \& Angreani, A. (2019). Kesantunan Bahasa Guru Dalam Proses Belajar-Mengajar Di Smp Negeri 35 Makassar. Klasikal: Journal Of Education, Language Teaching And Science, 1(1), 75-80. Retrieved from http://www.journalfkipuniversitasbosowa.org/index.php/klasikal/article/view/13Arikunto Suharsimi. 2013. Prosedur Penelitian: Suatu Pendekatan Praktis, edisi revisi 2010. Jakarta: Rineka Cipta

Bogdan, Robert dan Taylor, Pengantar Metode Penelitian Kualitatif, Terjemahan oleh Arief Rurchan, (Surabaya: Usaha Nasional, 1992).।

Darmawan, F. A., \& Jainuddin, J. (2021). Augmented Reality-based Mathematics Worksheet for Online Learning During Covid-19 Pandemic. Indonesian Journal of Educational Studies, 23(2), 81-90.

Dipalaya, T. (2020). Field Experience Practices Based Lesson Study (Ls) To Improve Students Communication Skills And Collaboration. Klasikal: Journal Of Education, Language Teaching And Science, 2(1), 48-62.

Hadzic S, Dedic A, Gojkov-Vukelic M, Pasic E, Ozegovic L, Beslagic E (2009). Influence of candida infection on denture stomatitis. Acta Medica Academica, 38: 6.

Jainuddin, J. (2019). Peningkatan Hasil Belajar Matematika Melalui Latihan Menyelesaikan Soal Secara Sistematis Pada Siswa Kelas XI. IPA1 sma Negeri 2 Sungguminasa. Klasikal: Journal Of Education, Language Teaching And Science, 1(3), 44-52.

Jainuddin, J., \& Sirajuddin, S. (2020). Pengaruh Minat dan Kedisiplinan Siswa dengan Gaya Kognitif Field Indefendent terhadap Hasil Belajar Matematika Siswa SMK Farmasi Yamasi Makassar. Delta-Pi: Jurnal Matematika dan Pendidikan 


\section{Matematika, 9(2).}

Kridalaksana, Harimurti. 1993. Kamus Linguistik. Jakarta: PT Gramedia Pustaka Utama

Nababan, P.W.J. 1986. Sosiolinguistik. Bandung: Angkasa.

Rahardi, Kunjana. 2005. Pragmatik Kesantunan Imperatif Bahasa Indonesia. Jakarta: Erlangga.

Rustono. 1999. Pokok-Pokok Pragmatik. Semarang: CV. IKIP Semarang Press 